\title{
PENGARUH METODE KARYAWISATA FANTASI DI LINGKUNGAN SEKOLAH BERBANTUAN MEDIA MAJALAH DINDING TERHADAP KOMPETENSI PENGETAHUAN PPKn
}

\author{
I Gusti Ayu Nedya Sanistyasari ${ }^{1}$, Made Putra ${ }^{2}$, Ni Wayan Suniasih ${ }^{3}$ \\ Prodi Pendidikan Dasar, Universitas Pendidikan Ganesha, Singaraja, Indonesia \\ e-mail: ayu.nedya.sanistyasari@undiksha.ac.id ${ }^{1}$, madeputra@undiksha.ac.id $^{2}$, niwayan.suniasih@undiksha.ac.id $^{3}$
}

\begin{abstract}
Abstrak
Tujuan penelitian ini untuk mengetahui pengaruh metode karyawisata fantasi di lingkungan sekolah berbantuan media majalah dinding terhadap kompetensi pengetahuan PPKn siswa kelas V SD gugus VIII Mengwi Jenis penelitian ini merupakan eksperimen semu, dengan bentuk non-equivalent control group design. Populasi penelitian ini adalah seluruh kelas V SD Gugus VIII Mengwi yang terdiri dari 9 kelas sebanyak siswa 248 orang. Sampel ditentukan dengan teknik random sampling. Sampel penelitian ini adalah kelas VA SD No.3 Mengwi sebagai kelompok eksperimen sebanyak 30 siswa, dan kelas VA SD No. 1 Mengwi sebagai kelompok kontrol sebanyak 31 siswa. Data kompetensi pengetahuan PPKn dikumpulkan dengan instrumen berupa tes objektif pilihan ganda biasa berjumlah 31 butir, yang telah divalidasi. Data kompetensi pengetahuan PPKn dianalisis dengan uji-t. Hasil analisis diperoleh $\mathrm{t}_{\text {hitung }}=3,421$. Harga tersebut kemudian dibandingkan dengan harga $t_{\text {tabel }}$ dengan $\mathrm{dk}=59$ dan taraf signifikansi $5 \%$ sehingga diperoleh harga $t_{\text {tabel }}=2,000$, karena $t_{\text {hitung }}>t_{\text {tabel }}$ maka Ho ditolak, yang berarti terdapat perbedaan yang signifikan kompetensi pengetahuan PPKn antara kelompok siswa yang dibelajarkan melalui metode karyawisata fantasi di lingkungan sekolah berbantuan media majalah dinding dengan kelompok siswa yang dibelajarkan melalui pembelajaran konvensional pada siswa kelas V SD Gugus VIII Mengwi tahun ajaran 2019/2019. Rerata kompetensi pengetahuan PPKn kelompok eksperimen $\bar{X}=0,42>\bar{X}=0,20$ rerata kompetensi pengetahuan PPKn kelompok kontrol. Sehingga dapat disimpulkan, metode karyawisata fantasi di lingkungan sekolah berbantuan media majalah dinding berpengaruh terhadap kompetensi pengetahuan PPKn siswa kelas V SD Gugus VIII Mengwi tahun pelajaran 2018/2019. Disarankan kepada peneliti lain agar penelitian ini dapat digunakan sebagai refrensi untuk melaksanakan penelitian selanjutnya.
\end{abstract}

Kata kunci: karyawisata fantasi, lingkungan sekolah, madding

\begin{abstract}
The purpose of this study was to determine the effect of fantasy fieldwork methods in the school environment assisted by wall magazine media on the knowledge competencies of PPKn fifth grade Students of Mengwi cluster VIII SD This type of research is a quasi-experimental, non-equivalent control group design. The population of this study was all of the fifth grade students of Elementary School VII of Mengwi which consisted of 9 classes as many as 248 students. The sample is determined by random sampling technique. The sample of this study was the VA SD No.3 Mengwi class as an experimental group as many as 30 students, and the VA class SD No. 1 Mengwi as a control group of 31 students. PPKn's knowledge competency data was collected with an instrument in the form of a regular multiple choice objective test with 31 items, which had been validated. PPKn knowledge competency data was analyzed by t-test. The results of the analysis obtained thitung $=3.421$. The price then compared with the price of table with $d k=59$ and $5 \%$ significance level, so the ttable $=2,000$ is obtained, because of tcount $>$ ttable therefore Ho is rejected, which means there is a significant difference in PPKn knowledge competencies between groups of students who were taught through fantasy field trips in school environment which is assisted by wall magazine media with groups of students who were taught through conventional learning in fifth grade students of Elementary School VIII Mengwi 2019/2019 school year. The mean of the knowledge competency of the experimental group PPKn $(X)^{-}=0.42>(X)^{-}=0.20$ than the average knowledge competence of the control group PPKn. it can be concluded, the method of fantasy field trip in the school environment assisted by wall magazine media has an effect on the knowledge competence of PPKn fifth grade students of SD VIII Mengwi in the 2018/2019 academic year. It is recommended to other researchers so that this research can be used as a reference to carry out further research.
\end{abstract}




\section{Pendahuluan}

Pendidikan merupakan salah satu hal penting bagi kehidupan manusia. Tanpa adanya pendidikan manusia tidak akan memperoleh berbagi pengetahuan dan mengembangkan kompetensi yang dimiliki. Oleh karena itu, kesadaran akan pentingnya pendidikan perlu disadari dari sejak kecil. Terutama pada saat tingkat Sekolah Dasar, karena pada tingkat tersebut siswa mulai menerima berbagai pengetahuan yang dapat diterapkan secara langsung dalam kehidupan sehari-hari baik itu di lingkungan sekolah, keluarga maupun masyarakat.

Pembelajaran membutuhkan sebuah proses yang didasari dan cenderung bersifat permanen dan dapat mengubah perilaku seseorang. Pada proses pembelajaran terjadi proses mengingat dan disimpan ke dalam memori. Selanjutnya pembelajaran tersebut di praktekan ke dalam peristiwa di kehidupan sehari-hari. Sistem pembelajaran dapat dilaksanakan dengan cara membaca buku, belajar di ruang kelas maupun di luar kelas. Dalam pembelajaran sangatlah penting memperhatikan metode, model pembelajaran, strategi, media dan tidak terkecuali kurikulum yang diterapkan haruslah diperhatikan dengan baik, sehingga pembelajaran yang akan dilakukan mencapai tujuan yang diharapkan.

Undang-Undang Nomor 20 Tahun 2003 tentang Sistem Pendidikan Nasional memuat bahwa kurikulum merupakan seperangkat rencana dan pengaturan mengenai tujuan isi dan bahan pelajaran serta cara yang digunakan sebagai pedoman penyelenggaraan kegiatan pembelajaran untuk mencapai tujuan pendidikan.

Pada jenjang Sekolah Dasar yang menggunakan kurikulum 2013 dilaksanakan secara tematik integrasi dengan menggunakan pendekatan saintifik. Pembelajaran tematik integrasi adalah pembelajaran yang mengintegrasikan berbagai kompetensi dari muatan materi satu dengan muatan materi lainnya dalam suatu tema (Fadlillah,2014). Sedangkan, pendekatan saintifik merupakan pendekatan di dalam kegiatan pembelajaran yang mengutamakan kreativitas dan temuan-temuan siswa (Kosasih, 2014). Dalam pembelajaran tematik integrasi dengan menggunakan pendekatan saintifik tersebut kita dapat melihat bagaimana sikap, pengetahuan dan keterampilan yang dimiliki siswa, sehingga siswa bukan hanya memiliki kemampuan pengetahuan saja tetapi juga memiliki sikap dan keterampilan.

Kompetensi merupakan perpaduan dari pengetahuan, keterampilan, nilai dan sikap yang direfleksikan dalam kebiasaan berpikir dan bertindak. (Mulyasa,2008:37). Menurut Kunandar (2015:165) kompetensi pengetahuan atau kognitif adalah penilaian yang dilakukan guru untuk mengukur tingkat pencapaian atau penguasaan peserta didik dalam aspek pengetahuan yang meliputi ingatan atau hafalan, pemahaman, penerapan atau aplikasi, analisis, sintesis, dan evaluasi. Kompetensi pengetahuan mengacu pada kompetensi inti dan kompetensi dasar. Permendikbud RI No. 24 Tahun 2016 pasal 2 menyatakan kompetensi inti pada kurikulum 2013 merupakan tingkat kemampuan untuk mencapai standar kompetensi lulusan yang harus dimiliki seorang peserta didik pada setiap tingkat kelas sedangkan, kompetensi dasar merupakan kemampuan dan materi pembelajaran minimal yang harus dicapai peserta didik untuk suatu muatan materi pada masing-masing satuan pendidikan yang mengacu pada kompetensi inti.

Berdasarkan pasal 1 Permendikbud RI No. 24 Tahun 2016 menggunakan pendekatan tematik terpadu, kecuali mata pelajaran matematika, dan PJOK. Salah satu muatan materi yang digunakan sebagai wahana untuk mengembangkan dan melestarikan nilai luhur dan moral yang berakar pada budaya bangsa Indonesia yaitu muatan materi PPKn. Nilai luhur dan moral ini diharapkan dapat diwujudkan dalam bentuk perilaku kehidupan siswa sehari-hari, baik sebagai individu maupun anggota masyarakat dan Mahluk ciptaan Tuhan Yang Maha Esa (Susanto, 2013).

Sutoyo (2011:6) menyatakan,

tujuan PPKn adalah untuk menumbuhkan wawasan dan kesadaran bernegara, sikap serta perilaku yang cinta tanah air, bersendikan kebudayaan bangsa, wawasan nusantara dan ketahanan nasional kepada siswa, mahasiswa, calon ilmuan warga Negara Republik Indonesia yang menguasai ilmu pengetahuan dan seni yang dijiwai nilai-nilai Pancasila.

Jadi dapat dipahami PPKn bertujuan untuk menumbuhkan wawasan serta sikap perilaku cinta tanah air yang berlandaskan kebudayaan bangsa, yaitu Pancasila dan UUD 1945. Sehingga peserta didik dapat belajar dengan baik serta memliki karakter bangsa yang diharapkan berlandasakan Pancasila dan UUD 1945. Untuk itu muatan materi PPKn di dalam Kurikulum 2013 hendaknya lebih berlandaskan dengan nilai Pancasila dan UUD 1945, sehingga siswa tidak hanya 
unggul dalam pengetahuan saja tetapi juga memiliki pendidikan karakter yang baik sesuai dengan nilai luhur Pancasila serta UUD 1945.

Pentingnya PPKn diajarkan di Sekolah Dasar dapat menimbulkan pemahaman dan pembiasaan diri dalam kehidupan di sekolah atau di luar sekolah, karena materi PKKn menekankan pada pengalaman dan pembiasaan di dalam kehidupan sehari - hari. Selain itu perlunya PPKn diajarkan sejak dini agar siswa dapat memahami dan mampu melaksanakan hak dan kewajiban untuk menjadi warga Negara Indonesia secara santun, jujur, demokratis serta bertanggung jawab. Jadi dapat disimpulkan bahwa tujuan PPKn di sekolah dasar untuk menjadikan peserta didik warga Negara yang baik, dan dapat diharapkan menjadi bangsa yang cerdas, terampil, betanggung jawab serta disiplin.

Muatan materi PPKn di sekolah dasar dengan kurikulum 2013 tidak serta merta mengalami keberhasilan. Pada kenyataannya, berdasarkan hasil observasi yang diperoleh pada kelas $\mathrm{V}$ Gugus VIII Mengwi dalam proses pembelajaran yang berkaitan dengan muatan materi PPKn masih terdapat beberapa hal yang kurang dalam muatan materi PPKn. Hal tersebut dapat dilihat dari peran serta siswa dalam proses pembelajaran muatan materi PPKn yang masih harus ditingkatkan, siswa belum mampu mencari pengetahuannya secara mandiri sesuai dengan tuntutan kurikulum 2013. Selanjutnya setelah memperoleh pengetahuan siswa kurang mampu mengembangkan pengetahuan yang telah didapatkan, proses pembelajaran pada muatan materi PPKn dianggap kurang menarik oleh siswa, dan siswa lebih senang mengobrol dan bercanda saat jam pembelajaran berlangsung.

Pelaksanaan pembelajaran di kelas perlu dirancang agar lebih menarik dengan memperhatikan karakteristik siswa kelas $\mathrm{V}$ sekolah dasar. Dari permasalahan tersebut dipandang perlu adanya inovasi dalam proses pembelajaran yaitu pembelajaran yang mengutamakan penguasaan kompetensi, berpusat pada siswa, menarik dan menyenangkan serta memberikan pengalaman belajar yang relevan dengan kehidupan nyata Salah satu metode pembelajaran yang dapat digunakan yaitu metode karyawisata fantasi di lingkungan sekolah berbantuan mading.

Pembelajaran dikatakan efektif apabila bermakna bagi siswa dan memudahkan siswa dalam memahami materi yang dipelajari dalam pembelajaran tersebut. Maka dari itu untuk mewujudkan hal tersebut, terkait dengan hal yang mendukung pada proses pembelajaran sekiranya perlu diperhatikan dan dipertimbangkan dengan baik, salah satunya menggunakan metode pembelajaran selama proses belajar mengajar. Metode pembelajaran adalah cara yang digunakan untuk memudahkan kegiatan belajar belajar mengajar guna untuk mencapai tujuan pembelajaran yang telah ditetapkan. Salah satu metode yang dapat digunakan adalah metode karyawisata fantasi. Metode pembelajaran karyawisata fantasi adalah metode pembelajaran karyawisata fantasi adalah kunjungan ke luar kelas dalam rangka belajar menggunakan aktivitas imajinasi untuk membentuk tanggapan-tanggapan baru dengan pertolongan tangapan lama dan tidak harus sesuai dengan benda-benda yang ada, tidak mengambil tempat yang jauh dari sekolah dan tidak memerlukan waktu yang lama.

Pembelajaran yang dilakukan di luar kelas atau di luar sekolah, memliki arti yang sangat pentingnya untuk perkembangan peserta didik. Pembelajaran yang demikian dapat memberikan pengalaman langsung kepada peserta didik. Pengalaman langsung tersebut memungkinkan materi pelajaran akan semakin konkret dan nyata yang berarti pembelajaran akan lebih bermakna. Banyak keuntungan yang akan diperoleh ketika kita menggunakan lingkungan sebagai sumber belajar. Keuntungan tersebut adalah sebagai berikut. (1) Peserta didik mendapat informasi berdasarkan pengalaman langsung sehingga pembelajaran akan lebih bermakna dan menarik, (2) Pembelajaran menjadi lebih konkret, (3) Sesuai prinsip-prinsip dalam pendidikan, yaitu belajar harus dimulai dari hal-hal yang bersifat konkret ke abstrak, mudah/sederhana ke yang sulit/kompleks. Metode pembelajaran ini juga dapat dipadukan dengan media majalah dinding.

Majalah dinding atau yang biasa diakronimkan menjadi mading merupakan satu jenis media komunikasi massa tulis yang paling sederhana (Santoso, 2007). Majalah dinding merupakan miniatur sebuah koran dari segi perwajahan dan isinya. Satu rentangan perwajahan majalah dinding harus mencerminkan isi dari materi yang akan disampaikan. Materi dari mading harus disusun secara variatif dan harmonis sehingga secara keseluruhan perwajahan majalah dinding tampak menarik dalam bentuk kolom-kolom, bermacam-macam hasil karya seperti teka-teki silang, karikatur dal lain-lain. Ada tiga faktor pendukung dalam menyelenggarakan majalah dinding, yaitu 
penulis, illustration dan dokumentator. Ketiga faktor tersebut saling terkait satu dengan yang laindalam melahirkan majalah dinding yang berkualitas (Santoso, 2007). Ciri khusus yang dimiliki mading yaitu singkat, padat, jelas, dan komukatif. Singkat berarti menghindar pemilihan kata yang kurang ringkas. Padat berarti menggunakan jumlah kata sedikit, tetapi dapat menjangkau makna yang selengkap-lengkapnya. Jelas mengandung makna tidak membingungkan, dan komunikatif mengandung unsur yang mudah dipahami. Oleh sebab itu majalah dinding, pemilihan kata menjadi unsur penentunya. Meskipun bahasa majalah dinding bersifat ringkas, tidak berarti menggunakan singkatan-singkatan sebagai pengganti kata. Bila menggunakan singkatan, sebaiknya dipilih singkatan yang sudah bersifat umum. Pada usia Sekolah Dasar pastilah menyukai menggunakan media mading sebagai sumber belajar. Karena dapat menarik perhatian siswa dan siswa dapat lebih termotivasi dalam belajar.

Metode pembelajaran karyawisata fantasi adalah kunjungan ke luar kelas (out door) dalam rangka belajar menggunakan aktivitas imajinasi untuk membentuk tanggapan-tanggapn baru dengan pertolongan tangapan lama dan tidak harus sesuai dengan benda-benda yang ada dengan membawa siswa ke objek (imajinasi) yang akan dipelajari dan tidak mengambil tempat yang jauh dari sekolah dan tidak memerlukan waktu yang lama sehingga manusia dapat berorientasi dalam alam imajinir dan imajinasi manusia dapat melampaui dunia nyata didukung dengan lingkungan sekolah karena metode ini cocok diorientasikan di lingkungan sekolah. Berbantuan media mading, media ini dapat dijadikan siswa sebagai sumber belajar. Adapun langkah dari metode pembelajaran karyawisata fantasi di lingkungan sekolah berbantuan media majalah dinding yaitu, langkah persiapan, langkah pelaksanaan, dan tindak lanjut. Pada saat langkah persiapan guru dan siswa menetukan tujuan belajar, Menentukan objek yang harus dipelajari dan dikunjungi, dan Menentukan cara belajar siswa pada saat kunjungan dilakukan. Misalnya mencatat yang terjadi, mengamati suatu proses, bertanya atau wawancara. Pada saat langkah pelaksanaan guru akan memulai pembelajaran dengan cara memberikan penjelasan terlebih dahulu, kemudian siswa mengajukan pertanyaan dan mencatat hal-hal penting yang telah disampaikan dari hasil penjelasan maupun dari pertanyaan, siswa dapat mencari materi lewat media majalalah dinding. Pada saat langkah tindak lanjut siswa diminta mendiskusikan hasil yang dia ditemu di lingkungan sekolah, siswa melaporkan hasil yang telah didapat, dan siswa diminta untuk menceritakan kesannya selama pembelajaran.

Penerapan suatu metode pembelajaran sebagai inovasi dalam pelaksanaan suatu pembelajaran tentu tidak berhasil dengan baik apabila tidak dilakukan dengan perencanaan yang baik, dan penggunaan media pembelajaran juga mempunyai peranan penting dalam menentukan keberhasilan proses pembelajaran di sekolah dasar. Media pembelajaran merupakan salah satu komponen yang memiliki peranan penting dalam menunjang proses pembelajaran serta mempermudah penyampaian materi atau konsep kepada siswa. Untuk itu penerapan metode karyawisata fantasi ini akan dipadukan dengan media mading dan sekitar lingkungan sekolah. Media majalah dinding atau yang bisa diakronimkan menjadi mading merupakan satu jenis media komunikasi massa tulis yang paling sederhana. Maka dari itu dengan bantuan media mading dapat membuat media untuk mengkomunikasikan materi yang akan dipelajari. Peserta didik akan melakukan pembelajaran di lingkungan sekolah. Lingkungan sekolah akan dimanfaatkan sebagai sarana belajar. Dilihat kebanyakan peserta didik jenuh berada di dalam kelas karena itu peserta didik akan melakuakan pembelajaran di luar kelas. Faktanya di gugus VIII Mengwi metode ini belum pernah dilaksanakan.

Berdasarkan uraian tersebut, untuk mengetahui pengaruh metode karyawisata fantasi di lingkungan sekolah berbantuan media mading dapat berpengaruh terhadap kompetensi PPKn, maka perlu dibuktikan melalui penelitian yang berjudul "Pengaruh Metode Karyawisata Fantasi di Lingkungan Sekolah Berbantuan Media Mading Terhadap Kompetensi PPKn Siswa Kelas V SD Gugus VIII Mengwi Tahun ajaran 2018/2019". 


\section{Metode}

Penelitian ini dilaksanakan di kelas V SD Gugus VIII yang melibatkan sekolah dasar diantaranya SD No 1 Mengwi, SD No 2 Mengwi, SD No 3 Mengwi, SD No 4 Mengwi, SD No 2 Werdhi Bhuana, dan SD No 3 Werdhi Bhuana. Waktu penelitian terkait dengan penelitian ini dilaksanakan pada semester II mulai tanggal 11 April 2019 sampai dengan tanggal 13 Mei 2019, perlakuan sebanyak 6 kali pada kelompok ekperimen, dam 6 kali pada kelompok kontrol. Jumlah perlakuan yang diberikan telah disesuaikan dengan jam pelajaran terkait materi dalam penelitian ini yang telah diatur dalam kurikulum dan silabus. Dalam penelitian ini rancangan yang digunakan adalah rancangan eksperimen. Jenis penelitian yang digunakan adalah penelitian kuantitatif yaitu penelitian eksperimen dengan desain eksperimen semu (quasy experimental design). Bentuk desain eksperimen semu (quasy experimental design) yang digunakan dalam penelitian ini yaitu non-equivalent control group design.

Secara skematis, desain eksperimen semu (quasy experimental design) yang digunakan pada penelitian ini dapat diilustrasikan sebagai berikut.

Gambar 1.

Rancangan Kelompok Non-ekuivalen

\begin{tabular}{|llll|}
\hline $\mathrm{O}_{1}$ & $\mathrm{X}$ & $\mathrm{O}_{2}$ & (eksperimen) \\
\hline$\ldots \ldots \ldots \ldots \ldots \ldots \ldots .$. & \\
\hline $\mathrm{O}_{3}$ & & $\mathrm{O}_{4}$ & (kontrol) \\
\hline
\end{tabular}

(Setyosari, 2015:211)

Keterangan :

$\mathrm{O}_{1} \quad=$ kelompok eksperimen yang diberikan pre test

$\mathrm{O}_{2} \quad=$ kelompok eksperimen yang diberikan post test

$\mathrm{X} \quad=$ perlakuan

$\mathrm{O}_{3} \quad=$ kelompok kontrol yang diberikan pre test

$\mathrm{O}_{4} \quad=$ kelompok kontrol yang diberikan post test

Pada desain ini, keduanya diberikan pre test (O1 dan O3). Bedanya kelompok yang satu diberi perlakuan $(X)$, sedangkan kelompok yang lain tidak dikenai perlakuan tetapi dijadikan atau diperlakukan sebagai kelompok kontrol. Setelah perlakuan pada kelompok yang satu selesai, kedua kelompok sama-sama mendapatkan pengukuran pasca tes atau post test (O2 dan O4).

Pelaksanaan penelitian ini terdiri dari tiga tahap, yaitu tahap persiapan, tahap pelaksanaan dan tahap akhir. Pada tahap persiapan, kegiatan yang dilakukan yakni: (1) melakukan wawancara dengan kepala Gugus VIII Mengwi dan wali kelas V di masing-masing sekolah di Gugus VIII Mengwi untuk mengetahui ada atau tidaknya kelas unggulan di sekolah dasar yang ada di Gugus VIII Mengwi Tahun ajaran 2018/2019, (2) menyusun RPP (Rencana Pelaksanaan Pembelajaran), (3) mempersiapkan metode pembelajaran Karyawisata Fantasi di lingkungan sekolah berbantuan media mading, (4) mengkonsultasikan instrumen penelitian pre test dan post test bersama wali kelas dan dosen pembimbing, (5) mengkonsultasikan RPP bersama wali kelas dan dosen pembimbing, (6) mengadakan uji coba instrument penelitian soal post test, (7) menentukan sampel penelitian berupa kelas dari populasi dengan teknik random sampling, (8) memberikan pre test kepada 2 kelas yang terpilih menjadi sampel untuk membuktikan kesetaraan kelompok, (9) untuk kesetaraan kelompok, analisis data pre test dilakukan dengan uji-t, (10) melakukan pengundian untuk menentukan kelompok kelas eksperimen dan kelompok kelas kontrol. Pada tahap pelaksanaan, kegiatan yang dilakukan yaitu: (1) Menentukan sampel penelitian dari populasi yang tersedia (2) Sampel yang telah diperoleh kemudian ditentukan dua kelompok yang dijadikan kelas eksperimen dan kelas control. (3) Melaksanakan pre test untuk uji kesetaraan sampel (4) Menentukan kelompok yang dijadikan kelompok eksperimen dan kelompok kontrol (5) Memberikan perlakuan pada kelompok eksperimen berupa metode pembelajaran Karyawisata Fantasi di lingkungan sekolah berbantuan media mading dan pembelajaran konvensional. (6) Perlakuan diberikan sebanyak 6 kali di kelas eksperimen. Jumlah perlakuan 
yang diberikan telah disesuaikan dengan jam pelajaran terkait materi dalam penelitian ini yang telah diatur dalam kurikulum. Saat tahap akhir, kegiatan yang ditempuh yaitu: (1) memberikan post test pada akhir penelitian, baik untuk kelas eksperimen maupun kelas kontrol, (2) Hasil post test kemudian dianalisis untuk mengetahui pengaruh metode pembelajaran Karyawisata Fantasi di lingkungan sekolah berbantuan media mading terhadap kompetensi pengetahuan PPKn.

Dalam penentuan subjek penelitian, langkah awal yang dilakukan dalam penelitian ini adalah menentukan populasi yang akan diteliti. Populasi dari penelitian ini adalah seluruh siswa kelas $\mathrm{V}$ SD Gugus VIII Mengwi tahun ajaran 2018/2019, yang terdiri dari 9 kelas dalam 7 sekolah dasar yang berjumlah 242 siswa. Berdasarkan informasi yang diperoleh dari kepala gugus, kepala sekolah serta guru wali kelas di masing-masing SD Gugus VIII Mengwi bahwa kelas V dari 7 sekolah dengan 9 kelas yang ada di Gugus VIII setara secara akademik yang memiliki nilai ratarata tidak jauh berbeda. Dikatakan setara, karena pengelompokan siswa ke dalam kelas-kelas dari 7 sekolah yang ada disebar secara merata antara siswa yang memiliki kemampuan tinggi, sedang, dan rendah. Dari keterangan tersebut berarti tidak terdapat kelas unggulan maupun non unggulan.

Teknik pengambilan sampel pada penelitian ini adalah Random Sampling sehingga setiap kelas mendapatkan peluang yang sama untuk menjadi sampel penelitian. Random Sampling merupakan cara pengambilan sampel dengan memberikan kesempatan yang sama kepada anggota populasi untuk diambil menjadi anggota sampel (Agung, 2014). Dari hasil observasi dan wawancara dengan kepala gugus bahwa semua kelas V SD yang ada di Gugus VIII Mengwi setara dalam hal input dan output dari perolehan hasil belajar, yang berarti tidak ada kelas unggulan maupun non unggulan. Sehingga semua kelas V SD yang ada di Gugus VIII Mengwi mendapat peluang yang sama untuk menjadi anggota sampel. Pemilihan sampel penelitian ini tidak dilakukan pengacakan individu melainkan hanya pengacakan kelas. Kelas dipilih sebagaimana telah terbentuk tanpa campur tangan peneliti dan tidak dilakukannya pengacakan individu, kemungkinan pengaruh-pengaruh dari keadaan siswa mengetahui dirinya dilibatkan dalam eksperimen dapat dikurangi sehingga penelitian ini menggambarkan pengaruh perlakuan yang diberikan. "Teknik sampel random dapat dilakukan dengan beberapa cara, yaitu undian, ordinal, bilangan random" (Agung, 2014:72).

Untuk menentukan sampel, cara yang digunakan adalah dengan cara pengundian. Cara undian dilakukan dengan menulis semua kelas V di SD Gugus VIII pada masing-masing kertas yang jumlahnya 9 kelas, kemudian kertas digulung. Masukkan gulungan kertas ke dalam kotak dan lakukan pengundian untuk mendapatkan dua kelas. Setelah itu, dua kelas hasil pengundian diberikan pre test. Berdasarkan informasi yang diperoleh dari kepala gugus, kepala sekolah serta guru wali kelas di masing-masing SD Gugus VIII Mengwi bahwa kelas V dari 7 sekolah dengan 9 kelas yang ada di Gugus VIII setara secara akademik yang memiliki nilai rata-rata tidak jauh berbeda. Dikatakan setara, karena pengelompokan siswa ke dalam kelas-kelas dari 7 sekolah yang ada disebar secara merata antara siswa yang memiliki kemampuan tinggi, sedang, dan rendah. Dari keterangan tersebut berarti tidak terdapat kelas unggulan maupun non unggulan. Sehingga di dapat sampel penelitian ini adalah kelav V SD No. 1 Mengwi sebanyak 31 siswa sebagai kelompok kontrol dan SD No. 3 Mengwi sebanyak 30 siswa sebagai kelompok eksperimen.

Penelitian ini memiliki 2 variabel, yaitu variable terikat dan variable bebas. Variable terikat dalam penlitian ini adalah kompetensi pengetahuan PPKn siswa sedangkan variable bebas dalam penelitian ini adalah metode karyawisata fantasi di lingkungan sekolah berbantuan media majalah dinding.

Pada penelitian ini data yang dianalisis adalah data mengenai kompetensi pengetahuan PPKn siswa, sehingga untuk memperoleh data tersebut dalam penelitian ini menggunakan instrumen bentuk tes. Tes adalah alat untuk mengukur pengetahuan yang dimiliki seorang individu. Pada penelitian ini jenis tes yang digunakan tes objektif dalam bentuk pilihan ganda biasa dengan 4 pilihan jawaban (A, B, C atau D).

Sebelum tes diberikan kepada masing-masing kelompok, terlebih dahulu dilakukan validasi secara teoretis dengan menggunakan kisi-kisi yang divalidasi pada ahli. Selanjutnya dilakukan validasi empirik dengan jumlah responden 30 siswa. Dari hasil uji instrument meliputi uji dengan uji validitas, uji daya beda, tingakt kesukaran, dan uji reliabilitas sehingga diperoleh 31 butir soal yang dinyatakan layak digunakan dalam penelitian ini. 
Selanjutnya pelaksanaan penelitian dilakukan dengan perlakuan terhadap masing-masing kelompok. Kelompok eksperimen dibelajarkan dengan metode karyawisata fantasi di lingkungan sekolah berbantuan media majalah dinding. Sedangkan kelompok kontrol dibelajarkan dengan pembelajaran konvensional. Setelah diberi perlakuan kelompok sampel akan diberikan posttest. Hal tersebut dipergunakan untuk mengetahui kompetensi pengetahuan PPKn. Data yang digunakan untuk melakukan analisis pada penelitian ini adalah data gain skor yang dari hasil pretest dan posttest. Adapun rumus yang digunakan untuk menghitung gain skor ternormalisasi adalah sebagai berikut.

$$
\text { GSn }=\frac{\text { Gain Skor }}{\text { Skor } \max -\text { Skor pretest }}
$$

(Dantes, 2017 : 126)

Keterangan :

GSn

Gain skor

Skor max

Skor pretest

= gain skor yang dinormalisasi

= hasil dari skor posttest - skor pretest

= skor maksimal

= skor pretest

Analisis statistik inferensial adalah suatu cara pengolahan data yang dilakukan dengan cara menerapkan rumus-rumus statistik inferensial untuk menguji suatu hipotesis penelitian yang diajukan peneliti, dan kesimpulan berdasarkan hasil pengujian terhadap hipotesis (Agung, 2014:110). Dalam penelitian ini teknik analisis yang digunakan untuk menguji hipotesis menggunakan uji-t. Sebelum dilakukan uji-t, terlebih dahulu harus memenuhi uji prasyarat analisis, yaitu dengan uji normalitas sebaran data dan uji homogenitas varians. Uji normalitas sebaran data dilakukan untuk mengetahui apakah sebaran frekuensi atau data skor pada setiap variabel berdistribusi normal atau tidak. Apabila data berdistribusi normal, teknik analisis data menggunakan tes parametrik karena tes parametrik didasarkan pada pengukuran interval dari variabel terikat. Untuk mengetahui apakah sebaran data kompetensi pengetahuan PPKn siswa masing-masing kelompok berdistribusi normal atau tidak sehingga dapat menentukan teknik analisis datanya. Rumus yang digunakan untuk menguji normalitas sebaran data pada penelitian ini adalah Kolmogorov-Smirnov. Uji homogenitas dilakukan dengan tujuan untuk menunjukkan bahwa perbedaaan yang terjadi pada uji hipotesis benar-benar terjadi akibat adanya perbedaan antar kelompok, bukan sebagai akibat perbedaan dalam kelompok. Uji homogenitas varians dilakukan dengan uji fisher (uji F). Data yang telah diuji normalitas dan homogenitas, selanjutnya dilakukan uji hipotesis. Hipotesis yang diuji dalam penelitian ini adalah sebagai berikut. Ho :Tidak terdapat perbedaan yang signifikan kompetensi pengetahuan PPKn siswa yang dibelajarkan menggunakan metode karyawisata fantasi di lingkungan sekolah berbantuan media mading dengan siswa yang dibelajarkan menggunakan pembelajaran konvensional pada siswa kelas V SD Gugus VIII Mengwi. Analisis statistik yang digunakan untuk menguji penelitian ini adalah uji-t dengan rumus polled varians.

\section{Hasil dan Pembahasan}

\section{Hasil}

Kelas VA SD No. 3 Mengwi dalam penelitian ini sebagai kelompok kelas eksperimen. Setelah diberikan treatment dengan menerapkan metode pembelajaran Karyawisata Fantasi berbantuan media Majalah Dinding sebanyak 6 kali pada kelompok eksperimen, di akhir eksperimen siswa diberikan post test untuk memperoleh data kompetensi pengetahuan PPKn. Kemudian dicari data gain skor yang dinormalisasi dari hasil pretest dan posttest. Diperoleh rata-rata gain skor kompetensi pengetahuan PPKn siswa kelompok eksperimen yaitu, 0,42. Varians data kompetensi pengetahuan PPKn pada kelompok eksperimen yaitu 0,05 dan standar deviasi 0,22. 
Kelas VA SD No.1 Mengwi dalam penelitian ini sebagai kelompok kelas kontrol. Setelah diberikan pretest dilanjutkan dengan pembelajaran seperti biasa dengan pembelajaran konvensial sebanyak 6 kali pada kelompok kontrol, diakhir penelitian siswa diberikan posttest untuk memperoleh data kompetensi pengetahuan PPKn siswa. Kemudian dicari data gain skor yang dinormalisasi dari hasil pretest dan posttest. diperoleh rata-rata gain skor kompetensi pengetahuan PPKn siswa kelompok kontrol yaitu, 0,20. Varians data kompetensi pengetahuan PPKn pada kelompok kontrol yaitu 0,004 dan standar deviasi 0,06.

\section{Tabel 1}

Hasil Uji Normalitas Sebaran Data Gain Skor Ternormalisasi Kompetensi Pengtahun PPKn

\begin{tabular}{lllll}
\hline No & Sampel & $\begin{array}{l}\text { Nilai } \\
\text { Maksimum } \\
\mid \text { FT }- \text { Fs } \mid\end{array}$ & $\begin{array}{l}\text { Nilai } \\
\text { Kolmogorov } \\
\text { Smirnov }\end{array}$ & $\begin{array}{r}\text { Tabel } \\
-\end{array}$ \\
& Kelompok Eksperimen & 0,126 & 0,242 & Normal \\
\hline $\mathbf{1}$ & Kelompok Kontrol & 0,128 & 0,238 & Normal \\
\hline
\end{tabular}

Berdasarkan hasil uji normalitas sebaran data kelompok eksperimen diperoleh dari nilai | FTFs | tertinggi yaitu 0,126 nilai tersebut digunakan sebagai angka penguji normalitas sebaran data. Adapun jumlah data sebanyak 30 dan pengujian pada taraf signifikansi $5 \%$ maka nilai tabel penguji kolmogorov-smirnov yaitu 0,242 sehingga diperoleh perbandingan nilai | FT-Fs | terbesar < nilai tabel kolmogorov-smirnov yaitu 0,126 < 0,242.Berdasarkan hasil tersebut maka HO dapat dinyatakan diterima dan $\mathrm{Ha}$ dinyatakan ditolak. Sehingga dapat disimpulkan bahwa sebaran data kompetensi pengetahuan PPKn pada kelompok eksperimen berdistribusi normal.

Berdasarkan hasil uji normalitas sebaran data kelompok kontrol diperoleh dari nilai | FT-Fs | tertingi yaitu 0,128 nilai tersebut digunakan sebagai angka penguji normalitas sebaran data. Adapun jumlah data sebanyak 31 dan pengujian pada taraf signifikansi $5 \%$ maka nilai tabel penguji kolmogorov-smirnov yaitu 0,238 sehingga diperoleh perbandingan nilai | FT-Fs | terbesar < nilai tabel kolmogorov-smirnov yaitu $0,128<0,238$. Berdasarkan hasil tersebut maka HO dapat dinyatakan diterima dan $\mathrm{Ha}$ dinyatakan ditolak. Sehingga dapat disimpulkan bahwa sebaran data kompetensi pengetahuan PPKn pada kelompok kontrol berdistribusi normal.

Uji homogenitas dilakukan untuk menunjukkan bahwa perbedaan yang terjadi pada uji hipotesis benar-benar terjadi akibat adanya perbedaan antar kelompok, bukan sebagai akibat perbedaan dalam kelompok. Dari hasil analisis, diperoleh Fhitung $=1,015$ sedangkan Ftabel pada taraf signifikansi $5 \%$ dengan dk $(30,29)$ adalah Ftabel 1,85. Hal ini berarti Fhitung < Ftabel, sehingga data kedua kelompok memiliki varians yang homogen. Berdasarkan hasil uji prasyarat yang terdiri dari uji normalitas dan uji homogenitas varians, maka dapat disimpulkan bahwa kedua data kelompok sampel ialah berdistribusi normal dan memiliki varians yang homogen. Dengan demikian, uji hipotesis menggunakan uji-t dapat dilakukan.

\section{Tabel 2}

Hasil Analisis Uji-t Kelompok Sampel Penelitian

\begin{tabular}{|c|c|c|c|c|c|c|c|c|}
\hline No & Sampel & $\begin{array}{l}\text { Rata- } \\
\text { rata }\end{array}$ & Varians & Dk & $\mathbf{N}$ & $\mathbf{t}_{\text {hitung }}$ & $t_{\text {tabel }}$ & Kesimpulan \\
\hline 1 & Kelas eksperimen & 0,42 & 0,05 & \multirow[t]{2}{*}{59} & 30 & \multirow[t]{2}{*}{3,421} & \multirow[t]{2}{*}{2,000} & \multirow[t]{2}{*}{$\mathrm{H}_{0}$ ditolak } \\
\hline 2 & Kelas kontrol & 0,20 & 0,004 & & 31 & & & \\
\hline
\end{tabular}

Hasil analisis uji-t diperoleh thitung $=3,421$. Harga tersebut kemudian dibandingkan dengan harga t-tabel dengan $\mathrm{dk}=30+31-2=59$ dan taraf signifikansi $5 \%$ sehingga diperoleh harga ttabel $=2,000$, karena thitung $>$ ttabel maka Ho ditolak. Hal ini berarti terdapat perbedaan yang signifikan kompetensi pengetahuan PPKn antara kelompok siswa yang dibelajarkan melalui metode pembelajaran karyawisata fantasi di lingkungan sekolah berbantuan media majalah dinding dengan kelompok siswa yang dibelajarkan melalui pembelajaran konvensional pada siswa kelas V SD Gugus VIII Mengwi tahun ajaran 2018/2019. Rata-rata kompetensi pengetahuan IPA siswa kelompok eksperimen lebih dari 
rata-rata kompetensi pengetahuan IPA siswa kelompok kontrol $(X) \overline{=0,42>(X)}=0,20$ ). Sehingga dapat disimpulkan bahwa penerapan Metode pembelajaran karyawisata fantasi di lingkungan sekolah berbantuan media majalah dinding berpengaruh terhadap kompetensi pengetahuan PPKn siswa kelas V SD Gugus VIII Mengwi Tahun ajaran 2018/2019.

\section{Pembahasan}

Berdasarkan uji hipotesis yang diperoleh thitung $=3,421$ sedangkan pada taraf signifikansi $5 \%$ dan dk 59 diperoleh nilai ttabel $=2,000$ sehingga thitung $>$ ttabel. Dengan demikian maka $\mathrm{HO}$ ditolak. Hal ini menunjukkan terdapat perbedaan yang signifikan kompetensi pengetahuan PPKn siswa yang dibelajarkan menggunakan metode karyawisata fantasi di lingkungan sekolah berbantuan media majalah dinding dengan siswa yang dibelajarkan menggunakan pembelajaran konvensional pada siswa kelas V SD N Gugus VIII Mengwi Tahun Ajaran 2018/2019.

Dari perolehan nilai kompetensi pengetahuan PPKn pada kedua kelompok dapat diketahui bahwa kedua kelompok yang awalnya memiliki kemampuan setara, lalu setelah diberikan treatment yang berbeda, perolehan nilai kompetensi pengetahuan PPKn mengalami perbedaan. Kompetensi pengetahuan PPKn siswa pada kelompok eksperimen lebih baik apabila dibandingkan dengan kompetensi pengetahuan PPKn siswa pada kelompok kontrol.

Perbedaan yang signifikan kompetensi pengetahuan PPKn kelompok eksperimen dan kelompok kontrol terjadi karena perbedaan pemberian treatment yang diberikan saat pembelajaran. Kelompok eksperimen diberikan pembelajaran dengan menerapkan metode pembelajaran karyawisata fantasi di lingkungan sekolah berbantuan media majalah dinding memiliki nilai rata-rata yang lebih tinggi dibandingkan dengan kelompok kontrol yang menerapkan pembelajaran konvensional.

Penerapan metode karyawisata fantasi di lingkungan sekolah berbantuan media majalah dinding dapat meningkatkan faktor-faktor yang mempengaruhi kompetensi pengetahuan PPKn. Minat belajar siswa dapat ditingkatkan melalui kegiatan yang menyenangkan dalam proses pembelajaran, karena penambahan media majalah dinding sebagai media pembelajaran dan sumber belajar. Selain itu, siswa akan di ajak keluar kelas untuk melaksanakan pembelajaran. Kegiatan ini membuat siswa merasa sedang bermain, sehingga ketika pembelajaran berlangsung pada kelas eksperimen mereka terlihat bersemangat dan senang mengikuti pembelajaran. Interaksi siswa meningkat karena, pada metode ini siswa diberikan kesempatan untuk berdiskusi dan berinteraksi dengan kelompoknya dalam mencari informasi, memecahkan suatu masalah atau persoalan. Melalui diskusi kelompok, siswa berpikir bersama untuk mengolah informasi, maka semua anggota kelompok dapat memberikan tanggapan mereka masing-masing. Setiap siswa akan memperoleh pengetahuan yang sama, sehingga pembelajaran menjadi efektif dan efisien.

Menurut (Haryono, 2013 :75) metode karyawisata adalah suatu cara penguasaan bahan pelajaran dengan membawa kepada objek yang akan dipelajari yang terdapat di luar kelas atau di lingkungan kehidupan nyata. Kelebihan dari belajar di luar kelas menurut (Sudjana, 2007: 208) (1) Kegiatan belajar lebih menarik dan tidak membosankan siswa duduk di kelas berjam- jam, sehingga motivasi belajar siswa akan lebih tinggi, (2) Hakikat belajar akan lebih bermakna sebab siswa dihadapkan dengan situasi dan keadaan yang sebenarnya atau bersifat alamiah, (3) Bahan- bahan yang dapat dipelajari lebih kaya serta lebih factual sehingga kebenarannya lebih akurat, (4) Kegiatan belajar siswa lebih komprehensif dan lebih aktif sebab dapat dilakukan dengan berbagai cara seperti mengamati, bertanya atau wawancara, membuktikan atau mendemonstrasikan, menguji fakta dan lain- lain, (5) Sumber belajar menjadi lebih kaya sebab lingkungan yang dapat dipelajari bisa beraneka ragam seperti lingkungan sosial, lingkungan alam, lingkungan buatan dan lain- lain, (6) Siswa dapat memahami dan menghayati aspek-aspek kehidupan yang ada di lingkungannya, sehingga dapat membentuk pribadi yang tidak asing dengan kehidupan di sekitarnya, serta dapat memupuk cinta lingkungan. 
Berdasarkan hasil uji hipotesis yang diperoleh pada penelitian ini menunjukkan bahwa thitung $=3,421$ sedangkan pada taraf signifikansi $5 \%$ dan dk 59 diperoleh nilai ttabel $=2,000$ sehingga thitung > ttabel. Dengan demikian hasil penelitian ini juga mendukung hasil penelitian sebelumnya yang dilakukan oleh Muchsin (2013) yang menyimpulkan bahwa dari pengolahan data didapatkan thitung $=3,734$ dan ttab (pada taraf signifikasi $5 \%$ ) $=1,687$. hal ini berarti thitung > ttabel sehingga ini menunjukan bahwa terdapat perbedaan prestasi belajar kognitif antara kelompok eksperimen dan kontrol . Rata-rata hasil belajar siswa pada kelompok eksperimen sebesar 0,42 dan pada kelompok kontrol sebesar 0,20. Ini berarti prestasi belajar kognitif siswa pada kelompok eksperimen yang mengikuti pembelajaran menggunakan metode karyawisata lebih baik dari kelompok kontrol.

\section{Simpulan dan Saran}

Berdasarkan hasil penelitian dan pembahasan dapat disimpulkan bahwa metode karyawisata fantasi di lingkungan sekolah berbantuan media majalah dinding berpengaruh terhadap kompetensi pengetahuan PPKn siswa kelas V SD gugus VIII Mengwi tahun ajaran 2018/2019. Hal ini dibuktikan dari hasil analisis diperoleh thitung $=3,421$. Harga tersebut kemudian dibandingkan dengan harga ttabel dengan $\mathrm{dk}=59$ dan taraf signifikansi $5 \%$ sehingga diperoleh harga ttabel $=2,000$, karena thitung $=3,421>$ ttabel $=2,000$ maka Ho ditolak. Selain itu, Rerata kompetensi pengetahuan PPKn siswa kelompok eskperimen $\mathrm{X}^{-}=$ $0,42>X^{-}=0,20$ rerata kompetensi pengetahuan PPkn siswa kelompok kontrol. Kepada guru, Guru hendaknya dapat menambah wawasannya mengenai inovasi pembelajaran sehingga mampu menerapkan ataupun mengembangkan pembelajaran di kelas secara lebih inovatif dan bervariasi agar dapat memberikan dampak positif dalam meningkatkan kompetensi pengetahuan siswa. Salah satu model pembelajaran yang dapat diterapkan oleh guru adalah metode karyawisata fantasi di lingkungan sekolah berbantuan media majalah dinding.

Kepada Kepala Sekolah, Sekolah hendaknya menyediakan sarana yang maksimal untuk menunjang pembelajaran agar siswa semakin termotivasi untuk belajar dan memanfaatkan sarana tersebut untuk mengoptimalkan kompetensi siswa sehingga mutu sekolah menjadi semakin meningkat.

Kepada peneliti bidang sejenis, Peneliti lain diharapkan melakukan penelitian lebih lanjut pada materi pembelajaran yang berbeda atau dapat pula dilakukan penelitian lebih lanjut dengan menggunakan metode karyawisata fantasi di lingkungan sekolah berbantuan media majalah dinding pada sumber data/sampel yang berbeda khususnya pada muatan materi PPKn sehingga hasil penelitian benar-benar dapat menggambarkan keadaan sesungguhnya yang terjadi di lapangan.

\section{Daftar Pustaka}

Agung. A. A. G.2013.Evaluasi Pendidikan. Singaraja.

Agung. A. A. G.2014.Metodologi Penelitian Pendidikan. Yogyakarta :Aditya Media Publishing.

Dantes,Nyoman.2017.Metode Penelitian.Yogyakarta :Andi Offset

Hardini, Isriani,dll. 2012. Strategi Pembelajaran Terpadi (Teori, Konsep dan Implementasi). Yogyakarta:Famiia.

Kosasih. 2014. Strategi Belajar dan Pembelajaran Implementasi Kurikulum 2013.Bandung: Yraa Widya 
Peraturan Menteri Pendidikan Kebubudaya Republik Indonesia No. 20 Tahun 2016 Tentang Standar Kompetensi Lulusan Pendidikan Dasar dan Menengah

Peraturan menteri pendidikan kebudayaan Republik Indonesia No. 24 Tahun 2016 Tentang Kompetensi Inti dan Kompetensi dasar Pelajaran Pada Kurikulum 2013 pada Pendidikan Dasar dan Pendidikan Menengah. 2016

Santoso, Hari. 2007. "Majalah Dinding Sebagai Madia Untuk Meningkatkan Kemampuan Menulis dan Budaya Baca Siswa.

Setyosari, Punaji. 2015. Metode Penelitian Pendidikan dan Pengembangan. Jakarta: Prenadamedia Group

Sudijono, Anas. 2012. Pengatar Evaluasi Pendidikan. Jakarta: Rajawali Pers

Sugiyono. 2016. Statistika Untuk Penelitian. Bandung: Alfabeta

Sugiyono. 2017. Metode Penelitian Kuantitatif Kualitatif dan R\&D. Bandung: Alfabeta

Sutoyo. 2011. PPKn untuk Perguruan Tinggi. Yogyakarta: Graha IImu.

Widiasworo, Erwin. 2017. Strategi dan Metode Mengajar Siswa di Luar Kelas (Outdoor Lerning) secara Aktif, Kreatif, Inspiratif, dan Komunikatif. Yogyakarta: AR-Ruzz Media 